Original Research Article

\title{
Evaluation of analgesic activity of glucose in Swiss Albino mice
}

\author{
Velarul S., Shobanaarani*, Sathiya Vinotha, Ponnuswamy
}

Department of Pharmacology, Karpagam Faculty of Medical Sciences \& Research, Coimbatore, Tamil Nadu, India

Received: 17 July 2018

Accepted: 11 August 2018

\section{*Correspondence to:}

Dr. Shobanaarani,

Email: shobimadhu89@ gmail.com

Copyright: (C) the author(s), publisher and licensee Medip Academy. This is an openaccess article distributed under the terms of the Creative Commons Attribution NonCommercial License, which permits unrestricted noncommercial use, distribution, and reproduction in any medium, provided the original work is properly cited.

\begin{abstract}
Background: Pain is the first and foremost symptom which alerts us about the underlying diseases, injuries or inflammation. Varied treatments are followed for pain relief worldwide. Nowadays tramadol, a centrally acting opioid analgesic is used widely. There are evidences that sweet substances like sucrose produce analgesia through endogenous opioid system. Sucrose has been proved to produce analgesic effect in healthy neonates and also in animals. Likewise, analgesic effect of glucose has also been studied but only limited no. of studies available.

Methods: Swiss Albino mice of either sex (20-30g) were procured from the central animal house of KFMS and R, Coimbatore. Animals were maintained under controlled temperature and light conditions with food and water ad libitum. Mice were kept in the department to get acclimatized. 24 mice were divided into 4 groups $(n=6)$. Drugs were given orally after 12 hours of fasting. Group I was the control. Group II received standard-tramadol $(40 \mathrm{mg} / \mathrm{kg})$. Group III received glucose $(200 \mathrm{mg} / \mathrm{kg})$. Group IV received glucose $(400 \mathrm{mg} / \mathrm{kg})$.

Results: The latency period of glucose was significant $(\mathrm{p}<0.001)$ compared to controls and standard was significant $(\mathrm{p}<0.001)$ when compared to glucose by hot plate method.

Conclusions: Analgesic activity of glucose may be due to both central and peripheral inhibition of PG synthesis. This has been proved in previous studies. This study showed that glucose can be used as an add-on in non-diabetic patients with better compliance.
\end{abstract}

Keywords: Analgesia, Acetic acid, Glucose, Hot plate, Tramadol

\section{INTRODUCTION}

Pain is the most common ailment for which patients seek medical advice. Analgesics are drugs which decrease pain sensation by increasing the nociceptive threshold to external stimuli without altering consciousness. Both pharmacological and non-pharmacological interventions are available for management of pain. There are two main classes of analgesics currently available, the non steroidal anti-inflammatory drugs (NSAIDs) and Opioid analgesics, but they have significant side-effect like gastric ulceration/bleeding, analgesic nephropathy, increased risk of myocardial infarction, stroke and respiratory depression, constipation, physical dependence, addiction, respectively. ${ }^{1,2}$ Pain is the first and foremost symptom which alerts us about the underlying diseases, injuries or inflammations. To cure sometimes, to relieve often, to comfort always", is a $15^{\text {th }}$ century French description of the role of the physician. Nowadays pain management is a specialized field in patient care. Varied treatments are followed for pain relief worldwide. Nowadays Tramadol, a centrally acting opioid analgesic is used widely. ${ }^{3,4}$ Sweet substances like sucrose produce analgesia through endogenous opioid system has been widely acknowledged. It has been proved to produce analgesic effect in healthy neonates and also in animals. ${ }^{5,6}$ Various studies have shown that administration of oral sucrose, a disaccharide, raises the pain threshold, presumably mediated by endogenous opioids and could be used for that purpose. However, sucrose is not routinely used for pain. ${ }^{7,8}$ 
Likewise, analgesic effect of glucose has also been studied, but only by limited no. of studies are available. Glucose is a monosaccharide widely used by intravenous (IV) route in intensive care unit but not as an oral solution. The present study was undertaken to find out the effect of oral administration of glucose, in different strengths, on pain relief.

\section{METHODS}

The study was conducted in Department of Pharmacology, Karpagam Faculty of Medical Sciences after having obtained Ethical clearance from Animal Ethical Committee at Karpagam Faculty of Medical Sciences and Research, Coimbatore. All the animals were handled carefully as per the CPCSEA guidelines.

\section{Chemicals}

Tramadol (ACME Laboratories Ltd)-Standard drug and $0.6 \%$ Acetic Acid, Normal saline were used. ${ }^{9}$

\section{Experimental animals}

The 48 Swiss albino mice of either sex (20-30g) were procured from the central animal house of KFMS and R, Coimbatore. They were kept in polypropylene cages in 12:12 hours light:dark cycle, provided with standard laboratory diet and had water ad libitum. Food was withdrawn 12 hours before and during experimental hours.

\section{Acetic acid induced writhing test}

The 24 Swiss albino mice were taken for this study. The mice were divided into 4 groups of 6 animals in each. Group I was used as control receiving $0.5 \mathrm{ml}$ normal saline. Group II was given standard drug Tramadol $10 \mathrm{mg} / \mathrm{kg}$. Group III, IV received glucose in doses of 200 and $400 \mathrm{mg} / \mathrm{kg}$ respectively. Mice were intragastrically administered with test and control drugs 30 min before intraperitoneal injection of acetic acid $(0.6 \%)$. Then mice were placed in separate bell shaped transparent glass jars and numbers of abdominal constrictions (writhes) were counted over a period of 10 minutes commencing $10 \mathrm{~min}$ after injection of acetic acid. The difference in number of writhes in test group was compared with standard treated and control treated groups. ${ }^{10}$ The percentage increase/decrease in number of writhing (as index of analgesia) was calculated. The Percentage Inhibition was calculated by formula:

$\%$ Inhibition $=[(\mathrm{Wc}-\mathrm{Wt}) \times 100] / \mathrm{Wc}$

Where $\mathrm{Wc}=$ No. of writhes in control group, $\mathrm{Wt}=$ No of writhes in test group.

\section{Eddys hot plate method}

The 24 Swiss albino mice weighing 20-30g were used. Mice were intragastrically administered with test and control drugs $.1 \mathrm{hr}$ after the ingestion of drugs mice were placed on the hot plate, which consists of electrically heated surface. Temperature of the hot plate was maintained at $55^{\circ} \mathrm{C}$.

Responses such as jumping, withdrawal of the paws and licking of the paws were observed. The time period (latency period) when animals were placed and until responses occur was recorded by the stopwatch. The latency period was recorded after 0, 60, 90 and $120 \mathrm{~min}$. These values were compared with the standard drug tramadol and control normal saline. This model evaluates the central pain. ${ }^{11}$

\section{Statistical analysis}

The experimental data were expressed as mean \pm SEM. Statistical analysis was carried out by one way analysis of variance (ANOVA). A level for $\mathrm{p}<0.05$ was considered to be statistically significant. IBM SPSS statistics (C) IBM Corporation 2012 software was used for statistical analysis purpose.

\section{RESULTS}

\section{Acetic acid induced writhing test}

Glucose which was given orally $30 \mathrm{~min}$ before intraperitoneal injection of acetic acid significantly reduced the number of writhes. Significant inhibition of the writhing response was observed after the administration of glucose $400 \mathrm{mg} / \mathrm{kg}$ when compared to normal saline control group.

The number of writhes of glucose was less when compared to control whereas the number of writhes of standard drug (Tramadol) were less when compared to glucose and normal saline. When compared to control, the percentage inhibition of glucose was $58.33 \%$ at $200 \mathrm{mg} / \mathrm{kg}, 66.66 \% \mathrm{t}$ $400 \mathrm{mg} / \mathrm{kg}$ and that of the standard was $83.96 \%$ (Table 1 ).

Table 1: Analgesic activity by acetic acid induced writhing in Mice.

\begin{tabular}{|lll|}
\hline Groups & No. of writhes & \% Inhibition \\
\hline Group I (control) & $36.23 \pm 2.32$ & - \\
\hline Group II (standard) & $6.03 \pm 2.43^{\mathrm{c}}$ & 83.33 \\
\hline Group III & $15.34 \pm 2.23^{\mathrm{c}}$ & 58.33 \\
\hline Group IV & $12.66 \pm 2.04^{\mathrm{c}}$ & 66.66 \\
\hline
\end{tabular}

Each value is the mean \pm SEM for 6 mice, a $\mathrm{P}<0.05$; $\mathrm{b} \mathrm{P}<0.01$; $\mathrm{c}$ $\mathrm{P}<0.001$ compared with control. Data were analyzed by using One-way ANOVA

\section{Eddys hot plate method}

Thus, the latency period of glucose was significantly ( $\mathrm{P}$ $<0.001)$ good when compared to control at time period 60$120 \mathrm{~min}$, whereas the latency period of the standard was more significant $(\mathrm{P}<0.001)$ when compared to glucose at all-time intervals of experimentation (Table 2). 
Table 2: Analgesic activity by hot plate method in mice.

\begin{tabular}{|lllll|}
\hline \multirow{2}{*}{ Groups } & \multicolumn{2}{l}{ Reaction time in seconds } & & \\
& $\mathbf{0}$ min & $\mathbf{6 0}$ & $\mathbf{9 0}$ min & $\mathbf{1 2 0}$ min \\
\hline Group I (Control) & $3.02 \pm 0.02$ & $3.12 \pm 0.03$ & $3.92 \pm 0.148$ & $3.50 \pm 0.23$ \\
\hline Group II (Standard) & $3.23 \pm 0.08$ & $6.65 \pm 0.07$ & $7.82 \pm 0.06$ & $8.26 \pm 0.66$ \\
\hline Group III & $3.24 \pm 0.04$ & $7.42 \pm 0.20$ & $8.26 \pm 0.08$ & $8.57 \pm 0.27$ \\
\hline Group IV & $3.42 \pm 0.05$ & $7.77 \pm 0.29$ & $8.43 \pm 0.27$ & $8.68 \pm 0.32$ \\
\hline
\end{tabular}

Each value is the mean \pm SEM for 6 mice, a $\mathrm{P}<0.05$; b $\mathrm{P}<0.01$; $\mathrm{c} \mathrm{P}<0.001$ compared with control. Data were analyzed by using One-way ANOVA

\section{DISCUSSION}

The present study was conducted to evaluate the analgesic activity of glucose and to explore the mechanism of action. Pain is an unpleasant sensory and emotional experience associated with actual and potential tissue damage. Pain is produced by the excitation of nociceptors or their afferent free nerve endings. ${ }^{12}$ There are two types of pain, fast pain and slow pain, mediated through $\mathrm{A} \delta$ fibers and $\mathrm{C}$ fibers. Nociception is the mechanism; whereby noxious peripheral stimuli are transmitted to the central nervous system. Nociceptive fibers terminate in the superficial layers of the dorsal horn, forming synaptic connections with transmission neurons running to the thalamus. Nociceptors release glutamate, substance $P$ contributing to neurogenic inflammation. ${ }^{13,14}$

Gate control theory is constituted by transmission in dorsal horn. The dorsal horn transmission is inhibited by descending inhibitory pathways from the midbrain (periaqueductal grey area) and brain stem (nucleus raphe magnus). Enkephalin and 5-hydroxytryptamine are the main transmitters in this pathway. It causes both presynaptic and postsynaptic inhibition of incoming Type $\mathrm{C}$ and Type $\mathrm{A} \delta$ pain fibers where they synapse in the dorsal horn. ${ }^{15}$ Sweetening substances mainly modulates endogenous opioids and serotonin. $\beta$-endorphin, metenkaphalin, leu-enkephalin and dynorphin are the main endogenous opioids. The two enkephalins are found in the brain stem and spinal cord are known to involve in analgesia. ${ }^{16,17}$

Nerve fibers derived from the periventricular nuclei and from the periaqueductal grey area secrete enkephalin at their endings. Fibers originating in this area send signals to the dorsal horns of the spinal cord neurons to secrete enkephalin. The enkephalin cause both pre synaptic and postsynaptic inhibition of incoming Type $\mathrm{C}$ and Ad pain fibers where they synapse in the dorsal horns. Thus, the analgesic system block pain signals at the initial entry point to the spinal cord. ${ }^{18,19}$

The use of different methods for evaluating pain is important because analgesic effect may be due to one or more mechanisms. For this reason in this study we have used hot plate method for supraspinal analgesia and acetic acid induced writhing for spinal analgesia.

There is also a role for nitric oxide (NO) pathway in pain modulation in animals and humans. NO also mediates the peripheral and central antinociceptive effect of analgesic compounds such as opioids. The NO-cyclic guanosine monophosphate (NO/cGMP) signalling pathway has also been shown to play a pivotal role in developing tolerance to opioid analgesia. Nevertheless, the role for $\mathrm{NO}$ in nociception is very complex and diverse. Both inhibitory and promotive actions of NO have been reported in nociception and pain. ${ }^{20,21}$ so in this study glucose shows analgesic activity but less compared to standard tramadol.

\section{CONCLUSION}

Glucose, a sweetening agent produces analgesia by inhibiting PG synthesis, modulating endogenous opioids. It can be used as an add on drug for pain in non diabetic patients.

\section{Funding: No funding sources}

Conflict of interest: None declared

Ethical approval: The study was approved by the Institutional Animal Ethics Committee at Karpagam faculty of Medical Sciences and Research, Coimbatore, India

\section{REFERENCES}

1. Hardman JG, Limbird LE, Molinoff PA. Analgesicantipyretic and anti-inflammatory agents and drugs employed in the treatment of gout., 9th ed., The Pharmacological Basis of Therapeutics, McGraw-Hill, New York; 1996:617.

2. Wolfe MN, Lichtestein DR, Singh GN. Gastrointestinal Toxicity of Non-Steroidal Antiinflammatory Drugs. N Engl J Med. 1999;128.

3. Rani S, Gupta MC. Evaluation and comparison of antinociceptive activity of aspartame with sucrose. Pharmacological Reports. 2012;64:293-8.

4. Anseloni VC, Weng HR, Terayama R, Letizia D, Davis BJ, Ren K, et al. Age-dependency of analgesia elicited by intraoral sucrose in acute and persistentpain models. Pain. 2002;97:93-103. 
5. Irusta AEC, Savoldi M, Kishi R, Resende GCC, Freitas RL, Carvalho AD, et al. Psychopharmacological evidences for the involvement of muscarinic and nicotinic cholinergic receptors on sweet substance-induced analgesia in Rattus norvegicus. Neurosci Lett. 2001;305:115-8.

6. Stevens B, Yamada J, Ohlsson A. Sucrose for analgesia in newborn infants undergoing painful procedures. Cochrane Database Syst Rev. 2010;1:CD001069.

7. Kishi R, Bongiovanni R, de Nadai TR, Freitas RL, de Oliveira R, Ferreira CM, et al. Dorsal raphe nucleus and locus coeruleus neural networks and the elaboration of the sweet-substance-induced antinociception. Neurosci Lett. 2006;395:12-7.

8. Miyase CI, Kishi R, de Freitas RL, Paz DA, Coimbra NC. Involvement of pre- and post-synaptic serotonergic receptors of dorsal raphe nucleus neural network in the control of the sweet-substance-induced analgesia in adult Rattus norvegicus (Rodentia, Muridae). Neurosci Lett. 2005;379:169-73.

9. Mullican WS, Lacy JR. TRAMAP-ANAG-006 Study Group. Tramadol/ acetaminophen combination tablets and codeine/ acetaminophen combination capsules for the management of chronic pain: a comparative trial. Clin Ther. 2001;23:1429-45.

10. Prabhu VV, Nalini G, Chidambaranathan N, Kisan SS. Evaluation of anti inflammatory and analgesic activity of Tridax procumbens Linn against formalin, acetic acid and CFA induced pain models. Int J Pharm Pharm Sci. 2011;3(2):126-30.

11. Tjolsen A, Rosland JH, Berge OG, Hole K. The increasing temperature hot-plate test: an improved test of nociception in mice and rats. J Pharmacol Meth. 1991;25:241-50.

12. Okuse K. Pain signaling pathways: from cytokines to ion channels. Int J Biochem Cell Biol. 2007;39:490-6.
13. Kidd BL, Urban LA. Mechanisms of inflammatory pain. Br J Anaesth. 2001;87:3-11.

14. Basbaum AI, Bautista DM, Scherrer G, Julius D. Cellular and molecular mechanisms of pain. Cell. 2009 Oct 16;139(2):267-84.

15. Segato FN, Castro-Souza C, Segato EN, Morato S, Coimbra NC. Sucrose ingestion causes opioid analgesia. Braz J Med Biol Res. 1997;30:981-4. [PubMed].

16. Bentley GA, Newton SH, Starr J. Studies on the Antinociceptive Action of Agonist Drugs and their Interaction with Opioid Mechanisms. Br J Pharmacol. 1983;79:125.

17. Ozdemir E, Bagcivan I, Durmus N, Altun A, Gursoy $\mathrm{S}$. The nitric oxide-cGMP signaling pathway plays a significant role in tolerance to the analgesic effect of morphine. Can J Physiol Pharmacol. 2011;89:89-95.

18. Chung E, Burke B, Bieber AJ, Doss JC, Ohgami Y, Quock RM. Dynorphin-mediated antinociceptive effects of L-arginine and SIN-1 (an NO donor) in mice. Brain Res Bull. 2006;70:245-50. [PubMed].

19. Kakeda T. Potential of sucrose-induced analgesia to relieve pain in male adults: A preliminary study. Jpn $\mathbf{J}$ Nurs Sci. 2010;7:169-73.

20. Blass E, Fitzgerald E, Kehoe P. Interactions between sucrose, pain and isolation distress. Pharmacol Biochem Behav. 1987;26(3):483-9.

21. Gradin M, Schollin J. The role of endogenous opioids in mediating pain reduction by orally administered glucose among newborns. Pediatrics. 2005;115:10047 .

Cite this article as: Velarul S, Shobanaarani, Sathiya V, Ponnuswamy. Evaluation of analgesic activity of glucose in swiss albino mice. Int J Basic Clin Pharmacol 2019;8:333-6. 